\title{
Cardiac Tissue Engineering
}

\author{
Matthew W. Curtis, M.S. ${ }^{1,2}$ and Brenda Russell, Ph.D. ${ }^{1,2}$ \\ 1 Department of Bioengineering, University of Illinois at Chicago \\ 2Department of Physiology and Biophysics, University of Illinois at Chicago
}

\begin{abstract}
The first two reviews in this series have described defining properties of stem cells, possible sources for them, and some initial attempts at their clinical use for tissue regeneration and repair. This third and final paper in the series describes bioengineering methods for building physical structures to contain and organize implanted cells. The relevant theory is that appropriate physical supporting structures will help implanted cardiac stem cell populations organize themselves into functioning cardiac tissue that integrates physically and functionally with the receiving heart. The purpose of cardiac tissue engineering is to replace or repair injured heart muscle effectively. Supporting materials to create habitable spaces can provide the basic requirements of cardiac muscle cells. The design of such supporting materials influences the behavior of cells; the shape, dimensions, and chemistry of substrates affects such processes as attachment, cell signaling, and differentiation. As cardiac muscle cells flourish in artificial environments they may become functional tissue with clinical value. This review summarizes the major bioengineering approaches for containing and organizing cardiac muscle cells - and their potential to ameliorate total heart failure.
\end{abstract}

\section{Introduction to Cardiac Tissue Engineering}

Damage to heart muscle, acute or chronic, has long been considered a tipping point for individual health outlook and progression to heart failure. National statistics are grim, with over 5 million affected by heart failure each year and nearly 300,000 deaths ${ }^{1}$. The problem is that adult heart muscle cells, cardiac myocytes, cannot divide to replace injured cells. Thus, despite a limited population of resident cardiac stem cells (described more thoroughly in the previous reviews of this series), the heart cannot repair itself by any native processes. Instead, scar tissue develops over regions of damaged myocardium. Such scar tissue keeps the organ intact but cannot contract. The ideal clinical intervention would either avoid such scar formation, or simply replace formed scar tissue with functioning cardiac muscle tissue. In a first approach to such therapy, investigators have used injections of new cells into damaged areas of cardiac tissue. These studies have met with limited success due to cell death, exit of cells from the heart, and poor cellular integration with the receiving heart tissue ${ }^{2-4}$.

It is known that cells have certain requirements for their survival in any surroundings. Many of those relate to the diffusion of available substances, with nutrients and oxygen flowing into cells while waste and signaling molecules are moved out. However, another less well known but essential requirement for nearly all cells is the need for a specific physical substrate. Most cell types, including cardiac myocytes, thrive only when attached to a suitable supporting surface. The purpose of tissue engineering is, then, to create a viable cellular environment through the use of biologically acceptable materials ${ }^{5}$. The idea is that transplantable cells can

Correspondence to: Department of Physiology and Biophysics (M/C 901), University of Illinois at Chicago, 835 S. Wolcott Avenue, Chicago, IL 60612-7342., E-mail: E-mail: russell@uic.edu, Telephone: (312) 413-0407, Fax: (312) 996-6312. 
be contained and organized in so-called engineered scaffolds. Such scaffolds with contained cells can then be used to treat or replace a part of the body 6 . Empty fabricated structures can also be implanted in vivo, providing a structure to condition stem cells already present.

For those helped by analogy, the efforts of tissue engineering can be compared to the building of a house. Home construction demands walls for stability, doors for transporting materials, plumbing and circuitry for moving water and electricity, and windows for circulation of oxygen. Analogous matters - anchorage, diffusion, integration, and vascularization, respectively - must be considered when engineering tissue. The purpose of such design is to make a livable structure. In the case of cardiac tissue, healthy, functional cardiac myocytes are the ideal inhabitants.

\section{Identifying Basic Cell Responses}

Flat, two-dimensional (2D) culture dishes have dominated studies of cell biology in the past. However, planar surfaces are hardly fitting for most cell types. To that end, there has been some understanding as to what physical features are important for the design of a three dimensional (3D) structure to support cardiac cells. It is possible, with that understanding, to begin modeling effective local microenvironments for cells (Figure 1).

Slight changes beyond a uniformly flat state can affect cardiac myocytes. Collagen, the most abundant constituent of the extracellular matrix, has a bundle diameter measured in the nanometer range - 100 to 1000 times smaller than the micrometer average cardiac myocyte diameter. Just as cells are influenced by extracellular proteins like collagen, so also are they capable of responding to artificial structures in the same size range. Indeed, cells have been shown to detect surface-deposited fibers manufactured in the nanometer scale. Meshes of electrospun nanofibers support cardiac myocyte adhesion and spontaneous contraction 7 . Projections in the micrometer scale can also directly affect cell behavior. Artificial projections with heights of five micrometers have been shown to cause both changes in cardiac myocyte shape and remodeling of cellular proteins responsible for substrate attachment ${ }^{8}$.

Stimuli other that surface topography can also have robust cellular consequences. Mechanical forces, either generated from cell contraction or sensed from external sources, have pronounced effects on differentiation, growth, and survival of myocardial cells ${ }^{9}$. For instance, experimentally exposing cardiac myocytes to repeated stretching in specific directions alters amounts of contractile proteins ${ }^{10}$. In addition, the stiffness of materials alone can modify some characteristics of cells. Softer, more elastic culture surfaces result in rounded cell shapes, irregular attachments, and higher motility ${ }^{11}$. Furthermore, when material or matrix stiffness is tuned to the range of native muscle rigidity (bearing a Young's modulus - a measure of resistance to deformation - between $8-17 \mathrm{kPa}$ ), mesenchymal stem cells are induced to differentiate into a myogenic lineage ${ }^{12}$. The clinical implications of controlling stiffness can be appreciated when it is recognized that collagen, a primary component of scar tissue that is overproduced in heart failure, has a relatively high stiffness 13 . Though designing around forces and stiffnesses may seem rudimentary, the interplay of these two physical elements has great significance for cardiac tissue engineering. Consider, for example, that each effective beat of the heart constitutes a precise balance between tension of contracting muscle and resistance held by the extracellular matrix. Once such relationships are fully understood, they can be used for therapeutic gain.

\section{Engineering Tissue in Three Dimensions}

The complexity of engineered systems increases considerably with the passage from two to three dimensions (Figure 2 and Table 1). As 2D becomes 3D, a host of new issues becomes significant. Here, levels of diffusion determine the degree of nutrient delivery and metabolic 
waste removal available to cells in the construct interior. The thickness of normal, diastolic, left ventricular myocardium is a little over one centimeter in the human heart, but there is a 200-micrometer tissue depth limit for the diffusion of oxygen ${ }^{14}$. Therefore, cell survival in $3 \mathrm{D}$ cardiac tissue constructs depends on angiogenesis and functional vascular integration to serve the remaining $95 \%$ of the heart wall.

Much of cardiac tissue engineering involves the struggle to perfect cellular organization without sacrificing tissue vascularization. The in vivo myocardium has a very dense layout, with overlapping arrays of muscle cells arranged in different circumferential orientations. Individual branched cardiac myocytes in the heart are linked to others at both ends through intercalated discs (containing gap junctions and other adherent sites) that help to transfer both molecular signals (e.g., electrical coupling) and forces of contraction. Studies have verified that a compact, end-to-end cardiac myocyte arrangement enhances electrophysiological connection and function ${ }^{15}$. Replicating this cellular organization of the myocardium has proved difficult.

The simplest $3 \mathrm{D}$ constructs that have been investigated to date are tiered 2D structures, in which individual flat levels are overlaid to form a cell-supporting lattice. One such study showed that overlapping electrospun meshes allows attached cardiac myocytes to have strong cellular contacts and synchronous beating after two weeks in culture ${ }^{16}$. In that study, five equal levels were formed with adequate diffusion, each showing in vivo-like cell morphology. It is also possible to pattern cells on a single substrate level and build up into 3D solely by attaching more cells. One group has demonstrated that lanes of cardiac myocytes on degradable polymer films can grow up to three cell layers thick and form organized, functional tissue ${ }^{17}$. Such geometric configurations constitute the very definition of tissue - an organized collection of cells working as a unit.

Some investigators have ignored scaffold patterning and studied tissue integrity in irregular environments. Preparations of cardiac myocytes bound to sponge-like alginate, a natural polymer derived from seaweed, have yielded vascularized cylindrical tissue nine weeks after implantation in rats ${ }^{18}$. In another example, porous nonwoven polyglycolic patches were seeded with embryonic stem cells and implanted on the ventricular surface of infarcted hearts in mice ${ }^{19}$. Within eight weeks, the polyglycol had degraded to natural byproducts, leaving a small area of active cells that contributed to an increased survival rate. Indeed, the

microenvironmental organization of cell-supporting materials can vary wildly but equally lead to positive experimental effects.

\section{More 3D Approaches and Considerations}

Extracellular matrix components such as collagen and fibrin can be used to make elastic gels with compositions similar to the body's extracellular matrix. Gels in unpolymerized form can be mixed with cells, and the result polymerized to create specific geometric shapes. In one study, collagen and cardiac myocytes were combined into circular molds, which displayed interconnected, beating cells when implanted around working rat hearts 20 . Gels and transplantable cells can also polymerize in vivo after injection, permitting the cell-matrix composite to assemble and conform to specific areas of the myocardium - though this relinquishes all control over final tissue shape. Two separate studies in rats have used, respectively, skeletal myoblasts in injectable fibrin matrices and embryonic stem cells in collagen matrices. Both studies reported small decreases in heart failure progression ${ }^{21,22}$. In yet another variation, unpolymerized gel-cell mixtures can be used to fill in the voids of other implantable scaffolds, thereby combining methods and materials into a complex structure for cells. Work of this sort has yielded healthy engraftment in rats ${ }^{23}$. With all these different gel setups, some problems remain. The use of natural proteins can trigger inflammatory responses 
in the body; the relatively low concentration of cardiac myocytes limits force of contraction; and once again, adequate vascularization can be a challenge - though the addition of endothelial cells (the cell type comprising all vessels) to gel mixtures can hasten new vessel formation $^{24}$.

In what may seem like a total surrender of engineering, another strategy for cardiac regeneration is to simply use the heart's own extracellular architecture. One study described the reseeding of whole decellularized donor rat hearts with major myocardial cell types including cardiac myocytes, fibroblasts, endothelial cells, and smooth muscle cells ${ }^{25}$. According to the report, original cells were removed with a detergent rinse, leaving the entire underlying extracellular matrix intact. In this way valves, chambers, and vascular channels are all preserved, allowing transplanted cells to move in and occupy familiar surroundings. Results were modest synchronous contractions were observed within several days, generating weak total pump function. Though human use would be feasible with cadaveric hearts (given that the extracellular matrix survives much longer than the cells it supports), the matter of repopulating the structure with appropriate stem cell sources would need to be addressed.

To increase the chance of successful implantation, bioengineers often treat cells in bioreactors before their use in vivo. A bioreactor is essentially a container filled with culture media that can be fine-tuned to stimulate cells in a number of ways. Continuous mixing of fluid within bioreactors helps to maintain an even concentration of nutrients. External forces such as pressure, strain, and shear stress can simulate the kinetic features of the heart. In one case, it was shown that a week of incubation in a bioreactor caused cardiac myocytes seeded in polyglycolic acid scaffolds to assemble into uniform, electrophysiological 3D tissue ${ }^{26}$. Another study with cardiac myocyte polyglycolic acid constructs confirmed that tissue thickness could be increased to a few millimeters by perfusing the media over cells ${ }^{27}$. Beyond this, other physical and chemical tweaks to bioreactor environments can enrich the conditioning process but cannot recapitulate the thickness of the ventricular wall in the human heart.

\section{Limiting Cells or Materials}

Though they can aid cell attachment and vascularization, the configurations of scaffolds, constructs, and gels are not easily optimized for transferring the contractile forces of the heart. Doing away with implanted materials altogether might have advantages. One group has shown progress in producing intact sheets of cardiac myocytes on a removable substrate, which can then be applied to regions of the myocardium as tissue patches ${ }^{28}$. In the study, three identical layers were carefully stacked and implanted in rat hearts. Since each triple layer had an 80micrometer thickness, one stack was implanted only to permit blood vessel penetration and cell integration. However, after a short time window, it was possible to repeat the surgery and add a new stack of cardiac myocytes directly over the previous set. By this method, a onemillimeter thick segment of tissue was created after 3 days. Though the stacks of cardiac myocytes were active and synchronized, the repetitive surgery technique has obvious difficulties for human treatment. Another group tested this same idea in rats with sheets of mesenchymal stem cells, which caused moderate recovery of cardiac function through vessel formation and cardiac myocyte differentiation ${ }^{29}$. These cell sheets may owe their effectiveness to the fact that cardiac myocytes are able to drive their own organization into rhythmicallybeating aggregates - without cues from a matrix or substrate ${ }^{30}$.

If all the technical problems of bioengineering functional heart tissue in animal models were solved, there would still be a major problem: there is at present no practical source of donor cells for replacement of human myocardium. Studies involving committed cardiac myocytes in scaffolds or constructs are almost universally taken from neonatal or adult rat hearts. Though such animal models have a physiological likeness that is well-suited for research, they represent 
a supply that is unacceptable for clinical use. Adult stem cells present the only feasible source for human treatment, but isolation, expansion, and differentiation into contractile cells remains difficult. Cell populations such as embryonic stem cells, mesenchymal stem cells from bone marrow, and umbilical cord stem cells have shown some therapeutic promise, though nonautologous cells bear an added risk of immune rejection (as detailed in both preceding articles in this series $)^{31,32}$. Very large quantities of differentiated cardiac myocytes are the necessary endpoint; a human myocardial infarction can injure 50 grams of cardiac muscle tissue, which would call for substitution of over one billion cells ${ }^{33}$. Any success in building the supply of cardiac myocytes from stem cells could eventually be coupled to the discussed housing concepts of tissue engineering.

Tissue engineering approaches need not all be cell-based. Pharmacologic agents can be linked to implanted scaffolds for controlled release. One of the more advanced cardiac-related examples of this makes use of injectable peptides that self-assemble into randomly branched networks; the resulting nanofiber microenvironments can be used to deliver drugs or growth factors ${ }^{34}$. Remarkably, an implanted structure alone can aid survival of myocardial cells following injury. For instance, fibrin matrices have been shown to increase vascularization, reduce scar formation, and preserve cardiac function when injected to damaged regions in rat hearts ${ }^{35}$. This concept can be expanded further, as demonstrated by the availability of external restraints. These bare polymeric supports are intended to wrap around the outer surface of one or both ventricles, thereby preventing wall stresses and maladaptive shape changes that may precede heart failure ${ }^{36}$. Indeed, in a conceptually simple application, clinical trials of degradable, passive restraints placed around the heart showed enhanced total cardiac function in hundreds of patients ${ }^{37}$. Though such improvements may be modest, this method of design represents a way of thinking that may produce new breakthroughs. Circumstances that would actually benefit from minimized engineering should not be overlooked.

\section{Thoughts and Conclusions}

The range of cellular and structural issues mentioned, it is evident that restoring or replacing cardiac muscle is no easy task. Based on findings from implanted cell constructs, clinically significant contractile improvements are quite rare. Poor electrochemical and vascular integration of cell constructs remain common reasons for low functional gains. In the bleakest of terms, it is quite possible that a cell-based approach to reversing myocardial damage is flawed entirely, posing great surgical risks for a minimal increase of cardiac output. However, given the high mortality rate and few end-stage alternatives, these research efforts comprise a worthy search. Many tissue engineering interventions certainly have potential, and new stem cell techniques are poised to help advance these treatments into the scope of cardiovascular nursing. As methods and disciplines merge, the ability to regenerate cardiac tissue is a goal with incalculable benefits - from benchtop to bedside.

\section{Acknowledgements}

The work was supported by NIH (HL 62426) and the State of Illinois funds for Regenerative Medicine.

\section{References}

1. American Heart Association. Dallas, Texas: AHA; 2008. Heart disease and stroke statistics - 2008 update.

2. Murry CE, Soonpaa MH, Reinecke H, et al. Haematopoietic stem cells do not transdifferentiate into cardiac myocytes in myocardial infarcts. Nature 2004;428(6983):664-668. [PubMed: 15034593] 
3. Zenovich AG, Davis BH, Taylor DA. Comparison of intracardiac cell transplantation: autologous skeletal myoblasts versus bone marrow cells. Handb Exp Pharmacol 2007;1(180):117-165. [PubMed: 17554507]

4. Teng CJ, Luo J, Chiu RC, Shum-Tim D. Massive mechanical loss of microspheres with direct intramyocardial injection in the beating heart: implications for cellular cardiomyoplasty. $\mathrm{J}$ Thorac Cardiovasc Surg 2007;132(3):628-632. [PubMed: 16935119]

5. Langer R, Vacanti JP. Tissue engineering. Science 1993;260(5110):920-926. [PubMed: 8493529]

6. Jawad H, Ali NN, Lyon AR, Chen QZ, Harding SE, Boccaccini AR. Myocardial tissue engineering: a review. J Tissue Eng Regen Med 2007;1(5):327-342. [PubMed: 18038427]

7. Shin M, Ishii O, Sueda T, Vacanti JP. Contractile cardiac grafts using a novel nanofibrous mesh. Biomaterials 2004;25(17):3717-3723. [PubMed: 15020147]

8. Motlagh D, Senyo SE, Desai TA, Russell B. Microtextured substrata alter gene expression, protein localization and the shape of cardiac myocytes. Biomaterials 2003;24(14):2463-2476. [PubMed: 12695073]

9. Samarel AM. Costameres, focal adhesions, and cardiomyocyte mechanotransduction. Am J Physiol Heart Circ Physiol 2005;289(6):H2291-H2301. [PubMed: 16284104]

10. Senyo SE, Koshman YE, Russell B. Stimulus interval, rate and direction differentially regulate phosphorylation for mechanotransduction in neonatal cardiac myocytes. FEBS Lett 2007;581(22): 4241-4247. [PubMed: 17698065]

11. Pelham RJ Jr, Wang Y. Cell locomotion and focal adhesions are regulated by substrate flexibility. Proc Natl Acad Sci U S A 1997;94(25):13661-13665. [PubMed: 9391082]

12. Engler AJ, Sen S, Sweeney HL, Discher DE. Matrix elasticity directs stem cell lineage specification. Cell 2006;126(4):677-689. [PubMed: 16923388]

13. Brower GL, Gardner JD, Forman MF, et al. The relationship between myocardial extracellular matrix remodeling and ventricular function. Eur J Cardiothorac Surg 2006;30(4):604-610. [PubMed: 16935520]

14. Radisic M, Malda J, Epping E, Geng W, Langer R, Vunjak-Novakovic G. Oxygen gradients correlate with cell density and cell viability in engineered cardiac tissue. Biotechnol Bioeng 2006;93(2):332343. [PubMed: 16270298]

15. Chung CY, Bien H, Entcheva E. The role of cardiac tissue alignment in modulating electrical function. J Cardiovasc Electrophysiol 2007;18(12):1323-1329. [PubMed: 17916158]

16. Ishii O, Shin M, Sueda T, Vacanti JP. In vitro tissue engineering of a cardiac graft using a degradable scaffold with an extracellular matrix-like topography. J Thorac Cardiovasc Surg 2005;130(5):13581363. [PubMed: 16256789]

17. McDevitt TC, Woodhouse KA, Hauschka SD, Murry CE, Stayton PS. Spatially organized layers of cardiac myocytes on biodegradable polyurethane films for myocardial repair. J Biomed Mater Res A 2003;66(3):586-595. [PubMed: 12918042]

18. Leor J, Aboulafia-Etzion S, Dar A, et al. Bioengineered cardiac grafts: A new approach to repair the infarcted myocardium? Circulation 2000;102(19 Suppl 3):III56-III61. [PubMed: 11082363]

19. Ke Q, Yang Y, Rana JS, Chen Y, Morgan JP, Xiao YF. Embryonic stem cells cultured in biodegradable scaffold repair infarcted myocardium in mice. Sheng Li Xue Bao 2005;57(6):673-681. [PubMed: 16344890]

20. Zimmermann WH, Melnychenko I, Wasmeier G, et al. Engineered heart tissue grafts improve systolic and diastolic function in infarcted rat hearts. Nat Med 2006;12(4):452-458. [PubMed: 16582915]

21. Christman KL, Fok HH, Sievers RE, Fang Q, Lee RJ. Fibrin glue alone and skeletal myoblasts in a fibrin scaffold preserve cardiac function after myocardial infarction. Tissue Eng 2004;10(3-4):403409. [PubMed: 15165457]

22. Kofidis T, de Bruin JL, Hoyt G, et al. Myocardial restoration with embryonic stem cell bioartificial tissue transplantation. J Heart Lung Transplant 2005;24(6):737-744. [PubMed: 15949735]

23. Krupnick AS, Kreisel D, Engels FH, et al. A novel small animal model of left ventricular tissue engineering. J Heart Lung Transplant 2002;21(2):233-243. [PubMed: 11834352]

24. Chekanov V, Akhtar M, Tchekanov G, et al. Transplantation of autologous endothelial cells induces angiogenesis. Pacing Clin Electrophysiol 2003;26(1 Pt 2):496-499. [PubMed: 12687876] 
25. Ott HC, Matthiesen TS, Goh SK, et al. Perfusion-decellularized matrix: using nature's platform to engineer a bioartificial heart. Nat Med 2008;14(2):213-221. [PubMed: 18193059]

26. Bursac N, Papadaki M, Cohen RJ, et al. Cardiac muscle tissue engineering: toward an in vitro model for electrophysiological studies. Am J Physiol 1999;277(2 Pt 2):H433-H444. [PubMed: 10444466]

27. Carrier RL, Rupnick M, Langer R, Schoen FJ, Freed LE, Vunjak-Novakovic G. Perfusion improves tissue architecture of engineered cardiac muscle. Tissue Eng 2002;8(2):175-188. [PubMed: 12031108]

28. Shimizu T, Yamato M, Kikuchi A, Okano T. Cell sheet engineering for myocardial tissue reconstruction. Biomaterials 2003;24(13):2309-2316. [PubMed: 12699668]

29. Miyahara Y, Nagaya N, Kataoka M, et al. Monolayered mesenchymal stem cells repair scarred myocardium after myocardial infarction. Nat Med 2006;12(4):459-465. [PubMed: 16582917]

30. Akins RE, Boyce RA, Madonna ML, et al. Cardiac organogenesis in vitro: reestablishment of threedimensional tissue architecture by dissociated neonatal rat ventricular cells. Tissue Eng 1999;5(2): 103-118. [PubMed: 10358218]

31. Breymann C, Schmidt D, Hoerstrup SP. Umbilical cord cells as a source of cardiovascular tissue engineering. Stem Cell Rev 2006;2(2):87-92. [PubMed: 17237546]

32. Schuleri KH, Boyle AJ, Hare JM. Mesenchymal stem cells for cardiac regenerative therapy. Handb Exp Pharmacol 2007;(180):195-218. [PubMed: 17554510]

33. Beltrami CA, Finato N, Rocco M, et al. Structural basis of end-stage failure in ischemic cardiomyopathy in humans. Circulation 1994;89(1):151-163. [PubMed: 8281642]

34. Davis ME, Hsieh PC, Takahashi T, et al. Local myocardial insulin-like growth factor 1 (IGF-1) delivery with biotinylated peptide nanofibers improves cell therapy for myocardial infarction. Proc Natl Acad Sci U S A 2006;103(21):8155-8160. [PubMed: 16698918]

35. Christman KL, Vardanian AJ, Fang Q, Sievers RE, Fok HH, Lee RJ. Injectable fibrin scaffold improves cell transplant survival, reduces infarct expansion, and induces neovasculature formation in ischemic myocardium. J Am Coll Cardiol 2004;44(3):654-660. [PubMed: 15358036]

36. Walsh RG. Design and features of the Acorn CorCap Cardiac Support Device: the concept of passive mechanical diastolic support. Heart Fail Rev 2006;10(2):101-107. [PubMed: 16258717]

37. Christman KL, Lee RJ. Biomaterials for the treatment of myocardial infarction. J Am Coll Cardiol 2006;48(5):907-913. [PubMed: 16949479] 


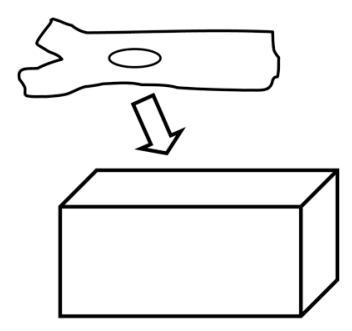

\section{MATERIALS AND DEGRADATION} Besides a noninflammatory composition, implantable materials must degrade steadily over time as native supports are built around cells.

\section{ATTACHMENT}

Cardiac myocytes are anchorage-dependent, meaning that in order to function they must adhere to surfaces.

\section{STIFFNESS}

The rigidity of a cell substrate affects cardiac myocyte

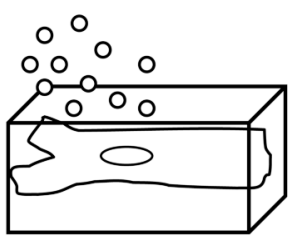
morphology and commitment of stem cells to lineages.

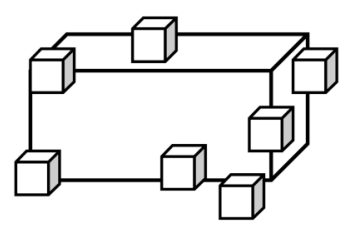

\section{DIFFUSION AND POROSITY}

Cells contained in 3D constructs risk poor diffusion of vital nutrients and gases, while porosity can shape the capacity for vascularization.

\section{FORCES}

Just as in regular beating of the heart, cardiac myocytes are sensitive to mechanical forces, both in strain magnitude and frequency.
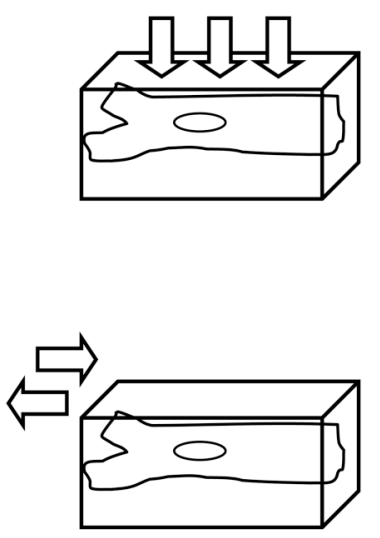

Figure 1.

Cell Responses to the Microenvironment. Depicted are several basic features of cell surroundings that must be taken into account when engineering $3 \mathrm{D}$ cardiac tissue. 


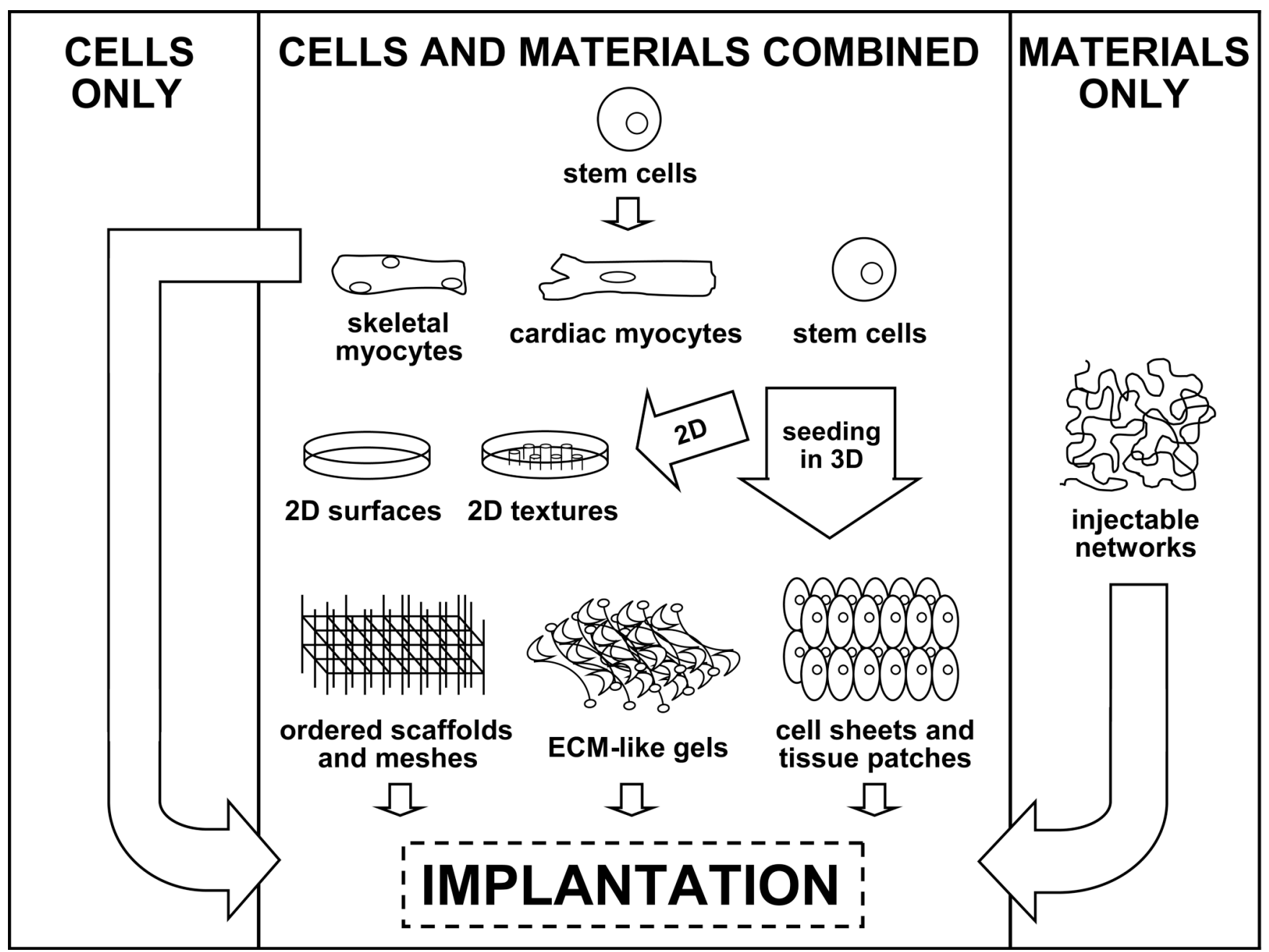

Figure 2.

Strategies of Cardiac Tissue Engineering. Shown are some of the different structural approaches for replacing cells of the myocardium. 
Table 1

Summary of Strategies. Corresponding to the various strategies mapped out in Figure 2, the advantages and disadvantages of notable cardiac tissue engineering approaches are listed.

\begin{tabular}{|c|c|c|c|}
\hline METHOD & $\begin{array}{c}\text { CLINICAL } \\
\text { ADVANTAGES }\end{array}$ & $\begin{array}{c}\text { CLINICAL } \\
\text { DISADVANTAGES }\end{array}$ & REFS \\
\hline \multicolumn{4}{|l|}{ Cells Only } \\
\hline Injection of cells & $\begin{array}{l}\text { No structure to design, less } \\
\text { invasive delivery }\end{array}$ & $\begin{array}{l}\text { High amount of cell exit or loss, } \\
\text { poor cell integration }\end{array}$ & {$\left[{ }^{2-4}\right]$} \\
\hline \multicolumn{4}{|l|}{ Cells + Materials } \\
\hline $\begin{array}{c}\text { Ordered scaffolds and } \\
\text { meshes }\end{array}$ & $\begin{array}{l}\text { Uniform support for cells, degrade } \\
\text { safely as cells incorporate }\end{array}$ & $\begin{array}{c}\text { Greater surgical risks for } \\
\text { implantation, limited vascularization }\end{array}$ & {$\left[\begin{array}{c}16,18,19 \\
25-27]\end{array}\right.$} \\
\hline ECM-like gels & $\begin{array}{l}\text { Similar composition to body, cells } \\
\text { readily attach }\end{array}$ & $\begin{array}{c}\text { Natural components can be } \\
\text { inflammatory, slow vascularization }\end{array}$ & {$\left[{ }^{20-24}\right]$} \\
\hline $\begin{array}{l}\text { Cell sheets and } \\
\text { tissue patches }\end{array}$ & $\begin{array}{l}\text { High cell density and organization, } \\
\text { less obstructive materials }\end{array}$ & $\begin{array}{l}\text { Surgery and placement difficult, } \\
\text { limited vascularization }\end{array}$ & {$[17,28,29]$} \\
\hline \multicolumn{4}{|l|}{ Materials Only } \\
\hline Injectable networks & $\begin{array}{l}\text { No immunogenic cells involved, } \\
\text { support placed where needed }\end{array}$ & $\begin{array}{l}\text { May require chemical factors, } \\
\text { inadequate repair without cells }\end{array}$ & {$[34,35]$} \\
\hline External restraints & $\begin{array}{l}\text { No immunogenic cells involved, } \\
\text { simple design and function }\end{array}$ & $\begin{array}{l}\text { Passive device, only prevents } \\
\text { spread of damage and stress }\end{array}$ & {$[36,37]$} \\
\hline
\end{tabular}

